\title{
Hasil belajar IPS menggunakan Kolaborasi Model Discovery Learning Berbasis Media Animasi
}

\author{
I Gede Darma Putra \\ Progaram Studi Pendidikan Guru Sekolah Dasar, FIP, Universitas Pendidikan Ganesha, Singaraja, Indonesia \\ Email: Darmaputra591@yahoo.com
}

I Wayan Sujana

Progaram Studi Pendidikan Guru Sekolah Dasar, FIP, Universitas Pendidikan Ganesha, Singaraja, Indonesia Email:Sujanawyn@gmail.com

I Komang Ngurah Wiyasa

Progaram Studi Pendidikan Guru Sekolah Dasar, FIP, Universitas Pendidikan Ganesha, Singaraja, Indonesia Email: Komang.wiyasa.@yahoo.com

\author{
A R T I C L E I N F O \\ Article history: \\ 1 Maret 2020 Received in \\ revised form \\ 30 Maret 2020 \\ Accepted 11 April 2020 \\ Available online 15 \\ Mei 2020

\section{Kata Kunci:} \\ Discovery learning, \\ Animasi, \\ Pengetahuan IPS \\ Keywords: \\ Discovery learning, \\ Animation \\ Social studies knowledge
}

\begin{abstract}
A B S T R A K
Pelajaran IPS adalah salah satu pelajaran yang ada di sekolah dasar yang bertujuan untuk mengembangkan sikap sosial anak. Pembelajaran IPS harusnya dibelajarkan dengan berpusat kepada siswa, akan tetapi proses pembelajaranya masih berpusat kepada guru dan menggunakan metode ceramah. Oleh karena itu penelitian ini bertujuan untuk menganalisis penggunaan model discovery learning berbasis media animasi. Penelitian ini adalah penelitian eksperimen semu rancangan nonequivalent control group design. Populasi penelitian ini adalah seluruh siswa kelas IV SD berjumlah 160 siswa. Sampel diambil dengan teknik random sampling. Sampel terdiri atas 31 orang kelas ekperimen dan 30 orang kelas kontrol. Pengumpulan data dilakukan dengan menggunakan metode tes dalam bentuk tes pilihan ganda. Data yang diperoleh dianalisis menggunakan uji-t. Hasil analisis data diperoleh thitnung $=3,302$ sedangkan pada taraf signifikansi $5 \%$ dan $\mathrm{dk}=59$ diperoleh nilai tabel $=2,000$ sehingga thitung $=3,302>$ tabel $=$ 2,000. Jadi, Penggunaan model discovery learning berbasis media animasi berdampak terhadap hasil belajar IPS. Adanya penelitian ini membantu guru untuk memperkaya referensi terhadap model pembelajaran yang bisa digunakan.
\end{abstract}

\section{A B S T R A C T}

Learning social studies in elementary school should be taught by focusing on students, but the learning process was still focused on the teacher and used lecturing method. Therefore, the aim of this research was to analyze the use of discovery learning models based on animation media. This research was quasi experimental research with non equivalent control group design. The population of this research was all fourth-grade elementary school students which were consisted of 160 students. The samples were taken by random sampling technique. The sample consisted of 31 students in experimental group and 30 students in control group. Data collection was done by using test in the form of multiple-choice test. The data were analyzed by using $t$-test. The results of data analysis obtained $t$-count $=3.302$ at a significance level of $5 \%$ and $d k=59$, the value obtained $t$-table $=2,000$ so that $t$-count $=3.302>t$-table $=2,000$. So, the use of discovery learning model based on animation media would have an impact on social studies learning outcomes.

\section{Pendahuluan}

Pendidikan memberikan kemungkinan pada siswa untuk memperoleh kesempatan, harapan, dan pengetahuan serta dapat menjadi kekuatan untuk melakukan perubahan agar sebuah kondisi menjadi lebih baik. (Sumarniti, 2014). Hal tersebut sangat bergantung pada kualitas pendidikan yang ditempuh tentunya melibatkan siswa untuk aktif belajar dan memperoleh nilai-nilai penting dalam pembelajaran yang dibutuhkan oleh siswa untuk menempuh kehidupan. Melalui pendidikan berbagai nilai dan keunggulan budaya dirinya, masyarakat, dan bangsa yang sesuai dengan zaman dimana siswa tersebut hidup dan mengembangkan diri. Pendidikan yang dilakukan seharusnya membentuk siswa yang memiliki karakter agar mereka tidak menyalahgunakan pengetahuan dan keterampilannya untuk merugikan orang lain. Hal ini sesaui dengan tujuan pendidikan yaitu menghasilkan peserta didik yang beriman dan bertakwa kepada Tuhan Yang Maha Esa, berhaklak mulia, sehat, berilmu, cakap, kreatif, mandiri dan menjadi warga negara yang demokratis serta bertanggung jawab. Salah satu pembelajaran yang dapat mengwujudkan tujuan tersebut adalah pelajaran IPS.

Pelajaran IPS adalah salah satu pelajaran yang dibelajarkan di SD yang menggabungkan Ilmu sosial antara lain geografi, sejarah, ekonomi, dan sesiologi. Secara sederhanya pelajaran IPS adalah pelajaran yang mengajarkan tentang proses interaksi antar manusia. Menurut Sardjiyo (2009:1.26) IPS adalah pelajaran yang 
mempelajari masalah sosial di masyarakat dengan meninjau dari berbagai aspek kehidupan atau satu perpaduan. Wachidi dalam Kunandar, (2008:262) Tujuan pelajaran IPS, yaitu 1) Mengajarkan kepada siswa untuk mengembangkan sikap. 2) Mengajarkan kepada siswa bagaimana berinteraksi dengan siswa lain 3) mengajarkan bagaimana hubungan manusia dan Tuhan. Berdasarkan penjabaran tersebut dapat dikatakan bahwa pembelajaran IPS sangatlah penting, oleh sebab itu pelajaran IPS harus dikemas sedemikan rupa agar tujuan dari pelajaran IPS tersebut dapat terwujud.

Kondisi kenyataannya berbeda dengan yang diharapkan, proses pembelajaran masih bersifat hapalan, guru masih menggunakan metode ceramah, guru jarang menugaskan siswa untuk memecahkan masalah, menggali masalah serta menyelesaikan masalah-masalah yang dihadapi. Dengan kata lain pembelajaran IPS masih bersifat teacher center. Kondisi tersebut sebenarnya tidak membuat siswa belajar, serta proses pembelajaran jadi sangat tidak bermakna. Berdasarkan hasil observasi yang dilakukan pada SD Gugus 2 Kecamatan Mengwi khususnya pada mata pelajaran IPS ditemukan bahwa pembelajaran di kelas berlangsung dengan menggunakan metode ceramah, tanya jawab dan penugasan. Metode ceramah, tanya jawab serta penugasan merupakan suatu metode pembelajaran yang tidak dapat dipisahkan dari suatu kegiatan pembelajaran. Hal ini secara tidak langsung mepengaruhi hasil belajar IPS. Hasil observasi ini juga didukung dengan hasil observasi yang dilakukan oleh Irayanti, dkk. (2018) menyatakan bahwa pembelajaran IPS masih rendah dan belum mencapai standar kriteria ketuntasan minimal yang telah ditetapkan. Rendahnya hasil pembelajaran IPS disebabkan oleh banyak faktor diantaranya: (1) Guru dalam mengimplementasikan pelajaran IPS saat ini masih bersifat konvensional. (2) Guru mengarahkan bahan IPS hanya berupa informasi yang tidak mengembangkan berpikir nilai. (3) Guru hanya membentuk budaya menghafal dan bukan berpikir kritis. Sementara dari segi siswa terlihat bahwa selama proses pembelajaran IPS, siswa hanya pasif didalam pembelajaran. (4) Hasil belajar siswa pada mata pelajaran IPS masih belum mencapai standar kriteria ketuntasan minimal yang telah ditetapkan oleh peneliti yaitu dari 43 orang siswa yang memperoleh nilai $\geq 70$ sebanyak 15 orang siswa atau hanya $34,88 \%$. Serta pendapat dari Syefnidar (2018) yang menyatakan bahwa rendahnya hasil UAS kelas III semester II ujian naik kelas Tahun Ajaran 2016/2017, banyak siswa yang tidak mencapai Kriteria Ketuntasan Minimum (KKM) yang telah ditetapkan yaitu 70. Hal itu dapat dilihat bahwa dari jumlah 17 orang siswa, hanya 29\% siswa yang mencapai ketuntasan belajar atau sebanyak 5 orang, sementara 12 orang atau $71 \%$ belum mencapai ketuntasan belajar yang telah ditetapkan. Dari data tersebut masih banyak siswa memperoleh nilai di bawah standar KKM yang ditetapkan sekolah yaitu 70 yang terlihat dari rata-rata nilai siswa yaitu 64, 08. Berdasarkan jabaran tersebut dapat dikatakan bahwa pembelajaran IPS belum terlaksana dengan baik. Kondisi seperti ini akan mempengaruhi hasil belajar IPS.

Hasil belajar adalah segala sesuatu yang diperoleh dalam proses pembelajaran, baik perubahan tingkah laku, pengetahuan, keterampilan ataupun sikap. Nana Sudjana (2009: 3) mendefinisikan hasil belajar perubahan tingkah laku sebagai hasil belajar dalam pengertian yang lebih luas mencakup bidang kognitif, afektif, dan psikomotorik. Dimyati dan Mudjiono (2006: 3-4) menyatakan bahwa hasil belajar adalah interaksi tindak belajar dan tindak mengajar. Hasil belajar sebagai salah satu indikator pencapaian tujuan pembelajaran di kelas. Untuk tercapainya hasil belajar, ada beberapa faktor yang menentukannya yaitu faktor berasal dari diri siswa dan dari laur diri siswa. Menurut, Sugihartono, dkk. (2007: 76- 77), faktor yang mempengaruhi hasil belajar, sebagai berikut: a) Faktor internal adalah faktor yang ada dalam diri individu yang sedang belajar. Faktor internal meliputi: faktor jasmaniah dan faktor psikologis. b) Faktor eksternal adalah faktor yang ada di luar individu. Faktor eksternal meliputi: faktor keluarga, faktor sekolah, dan faktor masyarakat. Hasil belajar yang baik dapat diperoleh apabila proses pembelajaran yang dilakukan berkualitas dan lebih bermakna. Akan tetapi masalah yang muncul berbeda dengan harapan. Untuk mengatasi masalah yang dipaparkan sebelumnya yaitu dengan cara menerapkan model pembelajaran yang inovatif. Salah satunya yaitu model discovery learning.

Model pembelajaran discovery adalah model pembelajaran penemuan, dimana siswa yang belajar menemukan serta belajar untuk memecahkan masalah yang diberikan dengan guru sebagai fasilitator dalam proses pembelajaran. Menurut Kurniasih \& Sani (2014) discovery learning adalah model pembelajaran yang tidak memberikan materi secara utuh, akan tetapi siswa yang menemukan materinya dan mengordinasikan pengetahuannya sendiri. Menurut Hosnan, (2013) Discovery Learning merupakan model pembelajaran siswa aktif menemukan sendiri, melalui ekperimen sederhana, dengan metode penyelidikan sendiri, sehingga pengetahuan yang diperoleh siswa akan bermakna serta lebih lama diingat. Jadi dapat dikatakan bahwa model discovery learning adalah model pembelajaran bersifat berpusat pada siswa, siswa belajar melalui penemuan, peneyelidikan dan ekperimen sederhana. Dengan adanya model ini mampu meningkatkan kempuan berfikir kritis siswa. Kurniasih \& Berlin (2014:66) Menyatakan bahwa kelebihan menggunakan model pembelajaran discovery learning adalah sebagai berikut: (a). Membantu siswa untuk memperbaiki dan meningkatkan keterampilan-keterampilan dan proses-proses kognitif. Usaha penemuan merupakan kunci dalam proses ini, seseorang tergantung bagaimana cara belajarnya. (b). Pengetahuan yang diperoleh melalui metode ini sangat pribadi dan ampuh karena menguatkan pengertian, ingatan dan transfer. (c). Berpusat pada siswa dan guru 
berperan sama-sama aktif. Bahkan gurupun dapat bertindak sebagai siswa, dan sebagai peneliti di dalam situasi diskusi.

Banyak penelitian yang sudah dilakukan oleh beberapa anatara lain Fitria, Ali, dan Rini (2017) menyatakan bahwa penggunaan model discovery learning dapat mempengaruhi hasil belajar matematika pada pokok bahasan Matriks. Penelitian yang dilakukan oleh I. S. Putri, R. Juliani, I. N. Lestari (2017) Penerapan model pembelajaran Discovery Learning dapat meningkatkan hasil belajar siswa dan aktivitas belajar siswa. Pendapat yang lain dari Mega, dkk (2015) menyatakan bahwa menunjukkan bahwa model Discovery Learning berpengaruh signifikan terhadap hasil belajar kognitif. Menurut Aprilia (2019) Model pembelajaran Discovery Learning merupakan model pembelajaran yang mengembangkan cara belajar aktif dan kreatif, dalam mengamati, menemukan, serta memecahkan masalah sendiri. Sehingga hasil yang didapat memberikan pengalaman langsung kepada siswa dan tidak mudah dilupakan siswa. Pembelajaran menggunakan model Discovery Learning dapat meningkatkan aktivitas siswa dalam pembelajaran, membuat siswa bersemangat dalam belajar, dan meningkatkan hasil belajar siswa. Jadi dapat disederhanakan bahwa model discovery learning adalah salah satu model pembelajaran yang berdampak positif terhadap hasil belajar siswa, karena dengan model ini akan mengaktifkan siswa belajar serta belajar akan lebih bermakna. Selain model pembelajaran hal yang tidak bisa terlepas dari proses pembelajaran adalah media. Salah satu media yang bias digunakan adalah media animasi.

Media adalah sarana penyampai informasi yang diberikan kepada siswa atau sarana perantara untuk menyajikan informasi dari guru kepada siswa, Media tersebut dapat berupa tulisan, gambar, suara, animasi dan video Toto Ruhimat, dkk. dalam Kadek Sukiyasa, Sukoco (2013). Menurut Nana dan Ahmad, 2011 membedakan beberapa jenis media yaitu; (1) media grafis meliputi; gambar, foto, grafik, bagan, poster, kartun, komik dan lain-lain; (2) media tiga dimensi dalam bentuk model meliputi; model padat, model penampang, model susun, model kerja dan lain-lain; (3) media proyeksi meliputi; slide, film strips, film, penggunaan Over Head Projector dan lain-lain, serta (4) media lingkungan. Menurut Mayer dan Moreno (2002, p.88) Animasi merupakan satu bentuk presentasi bergambar yang paling menarik, yang berupa simulasi gambar bergerak yang menggambarkan perpindahan atau pergerakan suatu objek. Penggunaan animasi dalam proses pembelajaran sangat membantu dalam meningkatkan efektifitas dan efisiensi proses pengajaran, serta hasil pembelajaran yang meningkat. Selain itu, penggunaan media pembelajaran khususnya animasi dapat meningkatkan daya tarik, serta motivasi siswa dalam mengikuti proses pembelajaran. Sedangkan manfaat dari media pembelajaran, Kemp \& Dayton (1985, pp.3-4) dalam Kadek Sukiyasa, Sukoco, 2013 yaitu: (1) penyampaian pengajaran bisa lebih standar; (2) pengajaran lebih menarik; (3) proses belajar menjadi lebih interaktif; (4) waktu penyampaian materi lebih singkat; (5) kualitas pengajaran menjadi meningkat; (6) pengajaran dapat dilakukan kapan dan dimana diinginkan serta dibutuhkan; (7) sikap positif siswa terhadap apa yang dipelajari dapat ditingkatkan; serta (8) dapat mengubah peran positif guru. Jadi dapat dikatakan dengan adanya media pembelajaran akan menyebabkan proses pembelajaran lebih menarik dan tentunya suasana kelas lebih menyenangkan.

Banyak penelitian yang dilakukan berkaitan dengan media animasi antara lain penelitian yang dilakukan oleh Kadek Sukiyasa (2013) terdapat pengaruh yang signifikan dari penggunaan media animasi terhadap hasil belajar dan motivasi belajar materi sistem kelistrikan otomotif. Pendapat dari Astrid dan Wirawan, (2017) menyatakan penggunaan media animasi mampu meningkatkan nilai hasil belajar siswa pada kompetensi dasar memproses bentuk permukaan. Sedangkan pendapat Devanti, Jumrodah (2015) menyatakan bahwa media animasi berpengaruh terhadap hasil belajar biologi pada konsep sistem peredaran darah manusia. Dari pendapat tersebut media dapat berdampak positif terhadap hasil belajar. Melihat kelebihan baik model discovery learning dan media animasi, maka akan menjadi hal yang meanarik jica mengkolaborasikan kedaunya. Oleh sebab itu tujuan yang ingin dicapai dalam penelitian ini adalah untuk mengetahui pengaruh mode discovery learning berbasis media animasi terhadap hasil belajar IPS siswa kelas IV SD Gugus 2 Kecamatan Mengwi tahun pelajaran 2016/2017. Penelitian ini diharapakan dapat memberikan kontribusi yang positif terhadap ilmu pendidikan, khususnya pendidikan guru sekolah dasar sehingga dapat memperluas pengetahuan tentang strategi atau pendekatan dalam proses pembelajaran untuk meningkatkan hasil belajar siswa.

\section{Metode}

Jenis penelitian ini adalah penelitian kuantitatif dengan desain eksperimen semu (quasi eksperiment) dengan rancangan non equivalent control group design. Populasi dari penelitian ini adalah seluruh siswa kelas IV SD Gugus 2 Kecamatan Mengwi tahun pelajaran 2016/2017 yang terdiri dari 5 kelas dalam 5 sekolah dasar yaitu SD No. 1 Munggu, SD No. 2 Munggu, SD No. 3 Munggu, SD No. 1 Tumbak Bayuh, SD No. 2 Tumbak Bayuh. Jumlah populasi dari penelitian ini adalah 160 orang. Teknik pengambilan sampel pada penelitian ini adalah random sampling. Untuk menentukan sampel, cara yang digunakan adalah dengan cara pengundian. Sampel dalam penelitian ini adalah siswa kelas IV SD No. 2 Munggu dengan jumlah 31 siswa sebagai kelompok eksperimen yang dibelajarkan menggunakan model discovery learning berbasis media animasi dan 
siswa kelas IV SD No. 3 Munggu dengan jumlah 30 siswa sebagai kelompok kontrol yang dibelajarkan dengan pembelajaran konvensional. Data yang dikumpulkan dalam penelitian ini adalah data hasil belajar IPS siswa kelas IV SD Gugus 2 Kecamatan Mengwi tahun pelajaran 2016/2017. Metode yang digunakan dalam pengumpulan data penelitian ini adalah metode tes. Metode analisis data yang dilakukan untuk uji hipotesis dengan menggunakan uji-t, terlebih dahulu dilakukan uji prasyarat analisis yang terdiri dari uji normalitas sebaran data dan uji homogenitas varians.

\section{Hasil dan Pembahasan}

Berdasarkan hasil analisis data hasil belajar IPS pada kelompok eksperimen, diketahui bahwa rerata hasil belajar IPS kelompok eksperimen $\bar{X}=80,10$ sedangkan rerata hasil belajar kelompok kontrol $\bar{X}=70,33$. Hasil uji normalitas data hasil belajar IPS kelompok eksperimen dengan model discovery learning berbasis media animasi $\mathrm{X}_{\text {hitung }}^{2}=4<\mathrm{X}_{\text {tabel }}^{2}=11,070$, maka data hasil belajar IPS kelompok eksperimen adalah berdistribusi normal. Sementara hasil uji normalitas data hasil belajar IPS siswa pada kelompok kontrol $\mathrm{X}^{2}$ hitung $(2,92)<X_{\text {tabel }}^{2}(11,070)$, maka data hasil belajar IPS siswa untuk kelompok kontrol adalah berdistribusi normal.

Hasil uji homogenitas varians data hasil belajar IPS yaitu $F_{\text {hitung }}=1$, 45. Pada taraf signifikansi $5 \%$ dengan dk pembilang $=30 \mathrm{dan} \mathrm{dk}$ penyebut $=29$ maka diperoleh harga $F_{\text {tabel }}$ adalah 1,84 . Karena $F_{\text {hitung }}=1,45$ $<\mathrm{F}_{\text {tabel }}=1,84$, maka hasil belajar IPS siswa pada kelompok eksperimen serta kelompok kontrol mempunyai varians yang homogen. Berdasarkan hasil uji normalitas dan homogenitas dapat diketahui bahwa data yang diperoleh dari kelompok eksperimen dan kelompok kontrol berdistribusi normal dan memiliki varians yang homogen. Karena data yang diperoleh telah memenuhi semua prasyarat, uji hipotesis dilakukan dengan menggunakan analisis uji-t.

Adapun kriteria pengujiannya adalah apabila $t_{\text {hitung }} \leq \mathrm{t}_{\text {tabel}}$, maka Ho diterima (gagal ditolak) dan Ha ditolak. Sebaliknya apabila $\mathrm{t}_{\text {hitung }}>\mathrm{t}_{\mathrm{tabel}}$, maka Ho ditolak dan Ha diterima.

Dengan $\mathrm{db}=\mathrm{n} 1+\mathrm{n} 2-2$ dan taraf signifikansi $5 \%(\alpha=0,05)$ atau taraf kepercayaan $95 \%$. Hasil uji t dapat dilihat pada Tabel 1.

Tabel 1. Tabel Hasil Analisis Uji-t Data Hasil belajar IPS

\begin{tabular}{lllllll}
\multicolumn{1}{c}{ Sampel } & $\mathrm{N}$ & $\mathrm{Dk}$ & $\bar{X}$ & $\mathrm{~s}^{2}$ & $t_{\text {hitung }}$ & $t_{\text {tabel }}$ \\
\hline Kelompok eksperimen & 31 & & 80,10 & 52,33 & & \\
Kelompok Kontrol & 30 & 59 & 70,33 & 76,46 & 3,302 & 2,000
\end{tabular}

Untuk mengetahui signifikansi hasil perhitungan uji hipotesis di atas, maka perlu dibandingkan dengan nilai $t_{\text {tabel. }}$. Harga $t_{\text {tabel }}$ dengan taraf signifikansi $5 \%$ dan $d k=59\left(n_{1}+n_{2}-2\right)=2,000$. Hasil analisis uji diperoleh $t_{\text {hitung }}=3,302$. Harga tersebut kemudian dibandingkan dengan harga $t_{\text {tabel }}$ dengan $\mathrm{dk}=31+30-2=59$ dan taraf signifikansi 5\% diperoleh harga $t_{\text {tabel }}=2,000$, karena $t_{\text {hitung }}=3,302>\mathrm{t}_{\text {tabel }}=2,000$ maka $\mathrm{H}_{\mathrm{o}}$ yang menyatakan tidak terdapat perbedaan yang signifikan hasil belajar IPS antara kelompok siswa yang dibelajarkan melalui model discovery learning berbasis media animasi karana dengan kelompok siswa yang dibelajarkan melalui pembelajaran konvensional pada kelas IV SD Gugus 2 Kecamatan Mengwi tahun pelajaran 2016/2017 ditolak atau $\mathrm{H}_{\mathrm{a}}$ diterima.

Berdasarkan hasil analisis uji t yang menyatakan terdapat perbedaan yang signifikan hasil belajar IPS antara kelompok eksperimen dengan kelompok kontrol siswa kelas IV SD Gugus 2 Kecamatan Mengwi tahun pelajaran 2016/2017, maka diperlukan uji lanjut untuk mengetahui pengaruh model discovery learning berbasis media animasi. Uji lanjut dilakukan dengan cara membandingkan rata-rata hasil belajarIPS kelompok eskperimen dengan rata-rata hasil belajar IPS kelompok kontrol. Nilai rata-rata hasil belajar IPS kelompok eskperimen $\bar{X}=80,10>\bar{X}=70,33$ hasil belajar IPS kelompok kontrol. Sehingga dapat disimpulkan bahwa model discovery learning berbasis media animasi berpengaruh terhadap hasil belajar IPS kelas IV SD Gugus 2 Kecamatan Mengwi tahun pelajaran 2016/2017. Dari perolehan hasil belajar pada kedua kelompok dapat diketahui bahwa kedua kelompok yang awalnya memiliki kemampuan setara, lalu setelah diberikan perlakuan yang berbeda perolehan hasil belajar IPS mengalami perbedaan. Hasil belajar IPS siswa pada kelompok eksperimen lebih baik apabila dibandingkan dengan hasil belajar IPS siswa pada kelompok kontrol. Kelompok eksperimen diberikan pembelajaran dengan model discovery learning berbasis media animasi memiliki nilai rata-rata yang lebih tinggi dibandingkan dengan kelompok kontrol. Hal ini disebabkan karena model discovery learning berbasis media animasi dapat membuat siswa antusias dan termotivasi dalam pembelajaran karena seluruh siswa dalam pembelajaran diberi kesempatan untuk berpartisipasi aktif dalam kegiatan pembelajaran. Model discovery learning berbasis media animasi memastikan setiap siswa mendapatkan kesempatan untuk berperan serta sehingga tidak ada lagi siswa yang bergantung pada teman sekelompoknya dan terdapat 
pemerataan tanggung jawab dalam kelompok. Model discovery learning berbasis media animasi siswa akan aktif untuk mencari suatu permasalahan dan memecahkan suatu permasalahan dalam pembelajran karena discovery learning proses pembelajaran yang melibatkan siswa untuk mengorganisasikan sendiri materi pelajaran dengan penekanan pada penemuan konsep atau prinsip yang sebelumnya tidak diketahui siswa. Apalagi dengan adanya media animasi pembelajaran akan lebih menarik dan menyenangkan dalam proses pembelajaran. Model discovery learning berbasis media animasi siswa lebih menarik dalam pembelajaran, dan dapat meningkatkan hasil belajar siswa. Hal ini sesuai dengan kelebihan discovery learning sebagai berikut: (a). Membantu siswa untuk memperbaiki dan meningkatkan ketrampilan-ketrampilan dan proses-proses kognitif. Usaha penemuan merupakan kunci dalam proses ini, seseorang tergantung bagaimana cara belajarnya. (b). Pengetahuan yang diperoleh melalui metode ini sangat pribadi dan ampuh karena menguatkan pengertian, ingatan dan transfer. (c). Berpusat pada siswa dan guru berperan sama-sama aktif. (Kurniasih \& Berlin (2014:66)). Sedangkan manfaat dari media pembelajaran, Kemp \& Dayton (1985, pp.3-4) dalam Kadek Sukiyasa, Sukoco, 2013 yaitu: (1) penyampaian pengajaran bisa lebih standar; (2) pengajaran lebih menarik; (3) proses belajar menjadi lebih interaktif; (4) waktu penyampaian materi lebih singkat; (5) kualitas pengajaran menjadi meningkat; (6) pengajaran dapat dilakukan kapan dan dimana diinginkan serta dibutuhkan; (7) sikap positif siswa terhadap apa yang dipelajari dapat ditingkatkan; serta (8) dapat mengubah peran positif guru. Jadi dapat dikatakan dengan adanya media pembelajaran akan menyebabkan proses pembelajaran lebih menarik dan tentunya suasana kelas lebih menyenangkan.

Penelitian ini diperkuat oleh penelitian yang relevan, yakni penelitian yang dilakukan oleh Putrayasa (2014) dengan judul "pengaruh model pembelajaran discovery learning dan minat belajar terhadap hasil belajar IPA siswa". Dengan hasil yang menunjukan adanya pengaruh dari model pembelajaran discovery learning terhadap hasil belajar IPA siswa besarnya koefisien ANAFA F (A) yaitu 5,689 yang signifikan. Selanjutnya terbukti bahwa besaran skor ratarata hasil belajar IPA kelompok siswa yang mengikuti model pembelajaran discovery learning $\left(\mathrm{A}_{1}\right)$ yaitu sebesar 74,70 yang lebih besar daripada rata-rata hasil belajar IPA kelmpok siswa yang mengikuti model pembelajaran kovensional $\left(\mathrm{A}_{2}\right)$ yaitu sebesar 70,78. Yang menyatakan bahwa terdapat perbedaan yang signifikan pada hasil belajar IPA siswa antara kelompok siswa yang dibelajarkan menggunakan pembelajaran konvensional. Penelitian yang dilakukan oleh Dila, Doddy, Arris (2017), menyatakan bahwa penggunaan media animasi pada mata pelajaran menggambar bentuk bidang di kelas X SMKN 4 Tangerang Selatan dapat mempengaruhi hasil belajar menjadi lebih baik/meningkat, dengan diadakannya penelitian ini maka diharapkan hasilnya dapat membantu pembelajaran sehingga lebih efektif dari segi waktu serta memudahkan siswa untuk lebih tertarik mengikuti pelajaran tersebut. hasil penelitian dari Haris Munandar*, Sutrio, Muhammad Taufik (2018) menyatakan bahwa terdapat pengaruh MPBM berbantuan media animasi terhadap kemampuan berpikir kritis siswa berupa peningkatan kemampuan dalam hal: (a) memfokuskan pertanyaan, (b) menganalisis argumen/mengidentifikasi alasan, (c) menginduksi dan mempertimbangkan hasil induksi, (d) mengevaluasi/menilai hasil pertimbangan, (e) memberikan alasan. Selain itu, MPBM berbantuan media animasi juga memiliki pengaruh terhadap hasil belajar fisika siswa berupa peningkatan hasil belajar fisika siswa dalam ranah kognitif. Hasil penelitian dari Ade Fitriani, Muhammad Danial, Dan Mohammad (2014) terdapat pengaruh positif penggunaan media animasi pada model discovery learning terhadap hasil belajar kimia. Serta penelitian Wahyu (2018), tentang model discovery learning berbantuan media animasi menyatakan bahwa model discovery learning berbantuan media animasi macromedia flash dapat meningkatkan aktivitas siswa kelas VIII pada materi tekanan. Dari penjabaran dan hasil penelitian dapat dikatan bahwa model discovery learning berbantuan media animasi dapat meningkatkan hasil belajar karena kolaboarsi model ini menyebabkan proses pembelajaran lebih menarik, menyenangkan, lebih meningkatkan rasa ingin tahu siswa dan tentunya hal ini secara tidak langsung akan membuat proses pembelajaran itu lebih aktif.

\section{Simpulan dan Saran}

Hasil analisis uji t diperoleh $t_{\text {hitung }}=3,302$. Harga tersebut kemudian dibandingkan dengan harga $t_{\text {tabel }}$ dengan $\mathrm{dk}=31+30-2=59$ dan taraf signifikansi $5 \%$ sehingga diperoleh harga $t_{\text {tabel }}=2,000$, karena $t_{\text {hitung }}>t_{\text {tabel }}$ $\mathrm{t}_{\text {hitung }}=3,302>\mathrm{t}_{\text {tabel }}=2,000$ maka $\mathrm{H}_{\mathrm{o}}$ yang menyatakan tidak terdapat perbedaan yang signifikan hasil belajarIPS antara kelompok siswa yang dibelajarkan melalui model discovery learning berbasis media animasi dengan kelompok siswa yang dibelajarkan melalui pembelajaran konvensional pada kelas IV SD Gugus 2 Kecamatan Mengwi tahun pelajaran 2016/2017 ditolak atau $\mathrm{H}_{\mathrm{a}}$ diterima. Hal ini berarti terdapat pengaruh model discovery learning berbasis media animasi terhadap hasil belajar IPS siswa kelas IV SD Gugus 2 Kecamatan Mengwi tahun pelajaran 2016/2017. Nilai rata-rata hasil belajar IPS kelompok eskperimen $\bar{X}=80,10>\bar{X}=70,33$ nilai rata-rata hasil belajar IPS kelompok kontrol. Sehingga dapat disimpulkan bahwa model discovery learning berbasis media animasi berpengaruh terhadap hasil belajar IPS kelas IV SD Gugus 2 Kecamatan Mengwi tahun pelajaran 2016/2017. 
Berdasarkan hasil penelitian ini, maka dapat diajukan beberapa saran guna peningkatan kualitas pembelajaran yaitu kepada guru diharapkan agar mencobakan menerapkan model discovery learning berbasis media animasi secara lebih lanjut untuk lebih meningkatkan kerjasama antara siswa dengan guru, siswa dengan siswa sehingga dapat meningkatkan kualitas pembelajaran sesuai dengan harapan. Kepada sekolah agar model discovery learning berbasis media animasi dapat dijadikan alternatif perbaikan kualitas pembelajaran dan mencapai tujuan pembelajaran yang diharapkan. Serta kepada peneliti lain yang berminat untuk melanjutkan penelitian ini agar mengembangkan masalah-masalah yang belum terjangkau dalam penelitian ini sehingga menjadi penelitian yang lebih sempurna dari penelitian ini.

\section{Daftar Pustaka}

Aprilia Rahmayani. 2019. Pengaruh Model Pembelajaran Discovery Learning dengan Menggunakan Mediavideo terhadap Hasil Belajar Siswa. Jurnal Pendidikan. Volume 04 Nomor 01 Tahun 2019 Halaman 59-62 e-ISSN: 2527-6891 DOI: 10.26740/jp. v4n1.p59—62.

Astrid dan Wirawan. 2017. Pengaruh Penggunaan Media Animasi Terhadap Hasil Belajar Siswa pada Kompetensi Dasar Memproses Bentuk Permukaan. Jurnal Pendidikan Teknik Mesin Vol. 17, No. 2, Desember 2017 (103-108). https://journal.unnes.ac.id/nju/index.php/JPTM/article/view/17631/8860.

Dimyati dan Mudjiono. 2006. Belajar dan Pembelajaran. Jakarta: PT Rineke Cipta

Fitriani, Adi, Muhammad Danial, Mohammad Wijaya. 2014. Pengaruh Penggunaan Media Animasi pada Model Discovery Learning terhadap Hasil Belajar Kimia Peserta Didik Kelas X MIA SMAN 1 Bungoro (Studi pada Materi Pokok Ikatan Kimia). Jurnal Chemica VOl. 15 Nomor 2 Desember 2014, 114 - 122. http://ojs.unm.ac.id/chemica/article/viewFile/4598/2643.

Fitriyah, Ali Murtadlo, dan Rini Warti. 2017. Pengaruh Model Pembelajaran Discovery Learning terhadap Hasil Belajar Matematika Siswa Man Model Kota Jambi. Vol. 9 No.2 Juni 2017 Halaman 108-112 http://dx.doi.org/10.22202/jp.2017.v9i2.1898.

Hosnan, M. (2013). Pendekatan Saintifik dan Kontekstual dalam Pembelajaran Abad 21 kunci sukses implementasi kurikulum 2013. Jakarta: Ghalia Indonesia.

Irayanti, Hamzah Upu, Thamrin Tahir, dan Muh. Yunus. 2018. Meningkatkan Hasil Belajar IPS Melalui Pendekatan Kontekstual Pada Siswa Kelas VB SDN Balang Baru 1 Kecamatan Tamalate Kota Makassar. Jurnal Ilmiah Pena Vol.1 Nomor 2 Tahun.

Kunandar. 2008. Langkah Mudah Penelitian Tindakan Kelas Sebagai Pengembangan Profesi Guru. Jakarta: Rajawali Pers.

Kurniasih, Imas dan Berlin Sani. 2014. Implementasi Kurikulum 2013 Konsep dan Penerapan. Surabaya: Kata Pena.

Kurniasih, Sani.2014. Strategi-Strategi Pembelajaran. Alfabeta: Bandung.

Dila Lestari, Dila, Doddy Rochadi, dan Arris Maulana. 2017. Pengaruh Media Pembelajaran Berbasis Animasi Terhadap Hasil Belajar Siswa Pada Materi Pelajaran Menggambar Bentuk Bidang Kompetensi Keahlian Teknik Gambar Bangunan Di Smkn 4 Tangerang Selatan. Jurnal Pendidikan Teknik Sipil Volume 6, No 2, Agustus 2017 Tersedia Online: http://journal.unj.ac.id/unj/index.php/jpensil.

Lestari, Mega, Maskun Maskun, dan Yustina Sri Ekwandar. 2015. PESAGI (Jurnal Pendidikan dan Penelitian Sejarah) Vol 3, No 4. http://jurnal.fkip.unila.ac.id/index.php/PES/issue/view/504.

Munandar, Sutrio dan Muhammad Taufik. 2018. Pengaruh Model Pembelajaran Berbasis Masalah Berbantuan Media Animasi Terhadap Kemampuan Berpikir Kritis Dan Hasil Belajar Fisika Siswa Sman 5 Mataram Tahun Ajaran 2016/2017. Jurnal Pendidikan Fisika dan Teknologi Volume 4 No.1, Juni 2018. http://jurnalfkip.unram.ac.id/index.php/JPFT/article/view/526.

Nana Sudjana. 2009. Penilaian Hasil Proses Belajar Mengajar. Bandung: PT Remaja Rosdakarya.

Putri, R. Juliani dan I. N. Lestari. 2017. Pengaruh Model Pembelajaran Discovery Learning Terhadap Hasil Belajar Siswa dan Aktivitas Siswa. Jurnal Pendidikan Fisika Vol.6 No.2 http://jurnal.unimed.ac.id/2012/index.php/jpfp-ISSN2252-732X e-ISSN 2301-7651.

Putrayasa, I Made. dkk. 2014. Pengaruh Model Pembelajaran Discovery Learning Dan Minat Belajar Terhadap Hasil Belajar Ipa Siswa. Jurnal Mimbar PGSD Universitas Pendidikan Ganesha. Jurusan PGSD (Vol: 2 No: 1 Tahun 2014). 
Sardjiyo dkk. 2009. Pendidikan IPS di SD. Jakarta: Universitas Terbuka.

Syefnidar.2018. Peningkatan hasil belajar siswa kelas IV pada pembelajaran IPS dengan menggunakan model Learning Starts with a question di SDN 14 Siguntur Muda Kecamatan Koto XI Tarusan Pesisir Selatan. Jurnal Penelitian Guru Indonesia - JPGI (2018) Vol 3 No 1 Print ISSN: 2541-3163 - Online ISSN: 25413317. https://jurnal.iicet.org/index.php/jpgi/article/download/158/201.

Sugihartono, dkk. 2007. Psikologi Pendidikan. Yogyakarta: UNY Press.

Sukiyasa, kadek dan Sukoco. 2013. Pengaruh Media Animasi Terhadap Hasil Belajar dan Motivasi Belajar Siswa Materi Sistem Kelistrikan Otomotif. Jurnal Pendidikan Vokasi, Vol 3, Nomor 1, Februari 2013. https://journal.uny.ac.id/index.php/jpv/article/view/1588. 